\title{
Regulating Biotechnology in the Age of Homeland Security
}

\author{
Judith Reppy
}

\begin{abstract}
The anthrax letters in the United States in October 2001, coming soon after the September 11 terrorist attacks, raised the fear of bioterrorism to a high level. Legislation to restrict access to select agents (i.e., those pathogens considered likely to be used in biological weapons) and to screen laboratory personnel for security risks soon followed; in addition, the major scientific journals in the field have agreed to practice self-censorship to prevent the publication of information that might be useful to terrorists. These developments are ushering in a new relationship between the field of biology and the state, raising important issues of governance. In this article I summarize the new regulatory regime, analyse its likely impact on the research community, and discuss the problems that the current approach to rule making creates for legitimacy and acceptance of the new regime.
\end{abstract}

Keywords: bioterrorism, governance, biotechnology

The promise of biotechnology for improving the human condition brings with it the possibility of malign use: there is a long history of the use of biological weapons in war, and before the Biological and Toxins Weapons Convention entered into force in 1975, most major states had active biological weapons programs. Although the Soviet Union maintained a large secret program into the 1990s and a number of smaller states are suspected of having clandestine programs, the main concern today is bioterrorism. Fears of 'alien' germs are not new (King, 2003), but the anthrax attacks in the United States in October 2001, coming soon after the 11 September terrorist attacks, raised the fear of bioterrorism to a high level. Legislation soon followed to restrict access to dangerous pathogens and to screen laboratory personnel for security risks. In addition, the major scientific journals in the field have agreed to practice self-censorship to prevent the publication of information that might be useful to terrorists. Along with the regulatory stick, there is a substantial carrot in the form 
of new federal funds for biological research on security-related topics. These developments in the United States are being echoed in other countries; for example, the European Union has announced a research program for security that will include biological research as a key element (Stafford, 2003).

The threat of bioterrorism and the regulatory response are ushering in a new relationship between the biological sciences and the state. Biologists now have to accept restrictions on research practices in the name of security, restrictions that appear more onerous than the familiar constraints imposed for safety reasons. New restrictions on sharing information go beyond the constraints involved in protecting intellectual property rights that are common in the biotechnology industry and industry-university consortia. The emerging security regime is, moreover, being constructed almost wholly from the top down. Participation in the process has so far been limited to government agencies and a few elite biologists: bench scientists, in particular, have been poorly represented. The governance issues raised by this modus operandi will affect the policy's success.

\section{Background}

National states have a profound interest in their own security - usually narrowly defined as military security. Indeed, one can argue that the modern state is a product of warfare and that its central function is to provide for the national security (Tilly, 1992). It follows that states take an interest in science and in scientists, whose knowledge-producing activities make them highly useful for devising new weapons and defences (Pearton, 1982). Conversely, national security needs have served the business of science well: no other purpose has proved so capable of generating sustained financial support for scientific research in the past half century, at least in those states committed to maintaining a strong military, such as the United States, the Soviet Union, France, Britain and China. In the United States, a decade after the end of the cold war, military and space programs continue to dominate federal spending for research and development (R\&D), and civilian goals are routinely recast as "wars" in order to take advantage of the rhetoric of national security.

The biological and medical sciences have had a part in this shared history of scientific development and national security (SIPRI, 1973; Cooter et al., 1998; Doel, 2003), but their role has been much smaller than that played by the physical and engineering sciences. Once the Biological and Toxin Weapons Convention entered into force in 1975, the development, production, stockpiling and transfer of biological weapons became illegal, and - with the exception of the Soviet Union, as noted above-statesponsored research in biological weapons was re-oriented to defensive measures and sharply curtailed. Coincidentally, the early 1970s also saw the beginnings of a revolution in biotechnology based on recombinant DNA techniques, a revolution that led to a reorientation of the biological sciences and a large increase in research activity in academia and industry. Because of the confluence of these two events, the contemporary biology community has had little experience with national security issues, and 
- unlike in the physical sciences - there is no network connecting biologists to the security community.

Instead, in the United States, the connections between biologists and the federal government run through the $\mathrm{Na}$ tional Institutes of Health, the National Science Foundation, and the Department of Agriculture. Significant private patronage for biological research comes from foundations such as the Howard Hughes Medical Institute, from the large multinational pharmaceutical companies, and from venture capital. The new biotechnology has been directed to civilian purposes - above all medical science - and biological research has been conducted largely in the open, except for proprietary constraints and those forms of information management that characterise research science in academia as well as industry (Hilgartner, 1997). In particular, it is commonplace for samples of biological agents and research results to be freely shared, and deviations from this norm - for example, Celera's decision not to release its map of the human genome - have been very controversial (Patrinos and Drell, 2002).

The terrorist attacks of 11 September 2001 and the subsequent anthrax letter attacks through the postal system, however, changed the political and social context for biological research as they did other aspects of state and society in the USA. Although there is some debate over the likelihood of a bioterrorist attack (Smithson and Levy, 2002: ch. 2; Leitenberg, 2003), in political circles the weight of opinion has favoured preparing for the worst. Current U.S. policy to reduce the risks of bioterrorism has two main components: policies to enhance public health measures, including im- proved capacity for early response to an attack, which are bundled under the rubric 'Project Bioshield'; and policies directed at creating a regulatory regime to reduce the risk that research in biotechnology could be used by bioterrorists. This article focuses on the latter set of policies and their impact on the research environment. ${ }^{1}$

\section{The New Regulatory Regime for the Life Sciences}

Prior to 2001, regulation of research in the life sciences in the United States and elsewhere was focused on biosafety issues and included rules governing laboratory design and research practices intended to protect workers and the general public from inadvertent release of biopathogens or potentially dangerous genetically engineered agents (National Research Council, 2003: ch. 2). Following the terrorist attacks, however, heightened concern about bioterrorism led Congress to pass two new laws affecting biological research. The PATRIOT Act of 2001 (PL 107-55) included language that extended pre-existing rules about the transfer of select agents to require registration by all laboratories possessing any select agent. 'Select agents' are those bacteria, toxins, and viruses identified by the U.S. government as posing a security risk for humans or agriculture, for example, smallpox, anthrax and Ebola. The original lists included all agents known to have been weaponised in the past; expanded lists were published in December 2002. ${ }^{2}$

The PATRIOT act also enumerated a class of restricted persons who are not allowed to have any access to select agents. 'Restricted persons' include any- 
one who has been indicted or convicted of a crime punishable by imprisonment of more than one year; fugitives from justice; unlawful users of any controlled substance; illegal aliens; persons who have been adjudged mental defectives or have been committed to a mental institution; nationals of any country designated by the U.S. Department of State as a state sponsor of terrorism (currently Cuba, Libya, Iran, Iraq, North Korea, Sudan, and Syria); and persons who have been dishonourably discharged from the U.S. armed forces. At least one of these categories is highly problematic: if the injunction against users of controlled substances were strictly enforced it would almost certainly have a crippling effect on research laboratories across the country.

The second law, the Bioterrorism Response Act of 2002 (PL 107-188), added to these strictures by increasing record keeping and reporting requirements for those laboratories possessing select agents; requiring enhanced physical security measures for the listed agents; and mandating FBI background checks - including fingerprinting - for all persons with access to the agents. The latter requirement, in conjunction with the restrictions of the PATRIOT Act, affects not only the employment of foreign scientists in the USA; it also applies to all scientists and non-scientists, such as custodial or secretarial staff, who may have access to laboratories in which research on select agents is being done. Both the PATRIOT Act and the Bioterrorism Response Act provide for criminal penalties, including prison sentences up to ten years, and put the onus for compliance on the individual scientist.

These laws provided the legislative foundation for a spate of regulations (42 CFR Part 73) covering biological and biomedical research which have been issued by the Centers for Disease Control and Prevention (CDC), the agency within the Department of Health and Human Services charged with implementing regulations on select agents that affect human health. A separate set of regulations (7 CFR Part 331 and 9 CFR Part 121), covering plant and animal pathogens, is administered by the Department of Agriculture. Other agencies that fund research on select agents, such as the Department of Defence and the Department of Energy, have also issued rules that are binding on their grantees. The result is a complex set of overlapping, and potentially incompatible rules, compounded by an unusually short timetable for implementation. Under the original schedule, institutions with laboratories doing work on select agents had to submit their plans for complying with the regulations by 12 June 2003 and be in full compliance no later than 11 November 2003. It proved impossible, however, for the FBI to carry out all the necessary background checks by the November deadline, so an indefinite extension has been granted (Perkel, 2003).

The new regulatory regime has a difficult task: biological agents are not so easily monitored or controlled as the nuclear and chemical materials that are the basis for other weapons of mass destruction. Instead of the limited number of repositories for nuclear materials, there are literally thousands of laboratories in the United States and around the world with one or more of the select agents. Moreover, a number of the select agents, such as anthrax, are widely present in nature (although converting 
a wild strain to an effective weapon is not an easy task). Because of the self-replicating nature of biological pathogens, the smallest diversion of material could be significant and almost certainly would be undetectable. Unlike nuclear materials, biological agents do not emit an identifying signal, and there is little to distinguish the activities of a wouldbe bioterrorist in the laboratory from those of the other scientists (Salerno et al., 2003).

Given these difficulties, it is clear that regulations alone are not going to be sufficient to establish control over access to select agents: the government will need the cooperation of the biologists themselves. Unfortunately, the new regulatory regime conflicts with the established research culture in the biological sciences, particularly the norm of sharing samples freely with other laboratories and the habit of never discarding a biological sample. In one well-publicised case, a research scientist at Texas Tech University has been indicted for allegedly lying about the disposition of samples of plague bacteria that he brought back with him from a trip to Tanzania; he faces the possibility of a prison sentence (Shane, 2003).

Some of the rules go beyond a clash with standard laboratory practices to impose inefficient and counter-productive constraints. For example, the twoperson rule, used to safeguard nuclear materials, has been suggested as a model for securing select agents. Under this rule, two people have to be present whenever a select agent is accessed. The result is a substantial increase in the cost of research, without a commensurate increase in security: as noted above, diversion of small amounts of biologically active material is for all practical purposes undetectable.

Administrative snafus marred the early implementation of the regulations - for example, universities were left off the initial list of institutions receiving the call to register possession of select agents - and there have been complaints about the timetable, the lack of clear language, and the inclusion of relatively innocuous organisms on the list of select agents (American Society for Microbiology, 2002a; 2002b). Faced with the bewildering complexity of the new rules and criminal sanctions for non-compliance, some scientists have responded by destroying their collections of samples and withdrawing from research with select agents (Elias, 2003). These events give credence to the fear that the regulatory regime may drive some established scientists from the field and make it difficult to recruit younger researchers to work on select agents.

\section{Other Problems, Other Initiatives}

The new laws and regulations in the United States mandate controls on access to select agents and better record keeping. In biology, however, as in other dual-use sciences, knowledge of laboratory techniques and successful (and unsuccessful) experiments could be just as dangerous in the hands of would-be terrorists as the physical possession of select agents. Unfortunately, access to information is not so easily controlled as access to laboratories, especially in a fast-moving field like biotechnology in which new ideas spread rapidly through global networks. The tension between the perceived security need to restrict access to potentially dangerous infor- 
mation and the benefits of openness in science is not new to the security field (National Academy of Sciences, 1982), but it is a problem that the biology community has not faced before. Nor is it clear that the arrangements negotiated for other scientific fields, such as nuclear physics and cryptography, will suit the case of the life sciences, with its thousands of laboratories and scientific journals (National Research Council, 2003: 63-67).

A precedent for keeping 'fundamental' research unclassified was set early in the Reagan administration. The government had moved to impose controls on information in unclassified settings, including universities and meetings of professional societies, and the ensuing controversy led to an influential report from the National Academy of Sciences (1982), followed three years later by a policy statement. National Security Decision Directive (NSDD) 189 reaffirmed the policy of keeping fundamental research in the open arena. It stated that:

It is the policy of this Administration that, to the maximum extent possible, the products of fundamental research remain unrestricted. It is also the policy of this Administration that, where the national security requires control, the mechanism for control of information generated during federally funded fundamental research in science, technology and engineering at colleges, universities and laboratories is classification. ${ }^{3}$

After the 11 September 2001 attacks, however, this policy of protecting fundamental research from classification again came under pressure. The Bush administration has left NSDD 189 in force, but it has added a category of "Sensitive But Unclassified Information"
(SBU) that should be protected from disclosure. The ambiguities surrounding the SBU category, which is nowhere clearly defined, have caused widespread concern (National Research Council, 2003: 69-70), and some universities have declared that they will not accept federal grants or contracts that include SBU controls (Ad Hoc Faculty Committee, 2002).

Even as the issues of classification and SBU were being debated, several research reports appeared in scientific journals which raised fears that open publication was producing blueprints for bioterrorists. The most troublesome, perhaps, was the mouse pox experiment, in which scientists in Australia inadvertently created a virulent version of the mouse poxvirus, one that killed even vaccinated mice. Although mouse pox does not affect humans, the technique appears to be equally applicable to smallpox. In another experiment, an American researcher successfully synthesised poliovirus from reagents purchased from commercial sources; publication of this result led a member of Congress to introduce legislation calling for controls on the publication of information that could be of use to bioterrorists (National Research Council, 2003: 19-23).

The editors of a number of leading scientific journals, responding to both the apparent dangers inherent in dualuse biotechnology and the looming threat of government action, met in January 2003 to consider voluntary policies for review of journal manuscripts. Their joint statement, published in Nature, Science, and The Proceedings of the National Academy of Sciences, calls upon the journals in the biological sci- 
ences to review each paper submitted for publication to determine if it raises security issues, and to refuse to publish if the issues cannot be addressed by modifying the paper (Journal Editors and Authors Group, 2003). In practice this amounts to another box to be checked off by editors and outside reviewers; to date the number of articles that have been challenged is very small (National Research Council, 2003: 71). Nevertheless, the editors' action has been quite controversial, with many commentators deploring the turn to censorship.

To sum up, the new regulatory regime for the life sciences has a number of components, some of which are mandated by federal legislation and apply to all researchers working with select agents, and others - the new journal review policies - that are voluntary, but not restricted to work on select agents only. The new rules are likely to have their largest impact on the conduct of university-based research, if only because industrial and government laboratories already operate under relatively tight controls on access and information sharing. In universities, however, the presence of even a single research project involving select agents will trigger requirements that will ripple out to affect all the laboratories sharing space in the same building or involving shared research students and post-docs.

\section{New Funding}

Along with the increase in government regulation have come increased funds for research on topics related to bioterrorism. Federal funding for research in the biological sciences has grown re- markably over the last three decades, culminating in the doubling of the budget of the National Institutes of Health (NIH) between FY 1999 and FY 2003. Just as the rate of increase was due to flatten out, a new growth area emerged: biodefence. A number of agencies are players, including NIH and the newly established Department of Homeland Security (DHS), which acquired an instant presence through the transfer of R\&D programs from other agencies. In the FY 2004 budget, the NIH is allocated US $\$ 1.6$ billion for biodefence and DHS's Directorate of Science and Technology gets US\$199 million for biological countermeasures plus US $\$ 70$ million for university programs (American Association for the Advancement for Science (AAAS), 2003b). The NIH total includes funds for basic research on the genomics of select agents; development of new vaccines and drugs; clinical trials for vaccines; and new facilities, including new BSL 3 and 4 laboratories at government installations and at universities (Kaiser, 2003).

Although the budgetary picture remains somewhat confused - for example, there are as yet no details on how DHS will allocate its R\&D funds, and the form of cooperation between DHS and NIH has yet to be spelled out - it is clear that the new biodefence research dollars represent a cornucopia for researchers in the biological sciences. The Director of the National Institute of Allergy and Infectious Diseases (NIAID), Anthony Fauci, testified in April 2003 that his institute had experienced a 30 percent increase in the number of grant applications in response to its biodefence initiatives (Fauci, 2003). The AAAS has described the research community as "ly[ing] in wait for funding opportuni- 
ties in the R\&D components of the new department [DHS]" (AAAS, 2003a: ch.12, 6 ), and the Chief Scientific Officer at Therion Biologics is quoted as saying: "There is always an opportunity for the biotech industry to access federal dollars. But this is probably one of the greatest opportunities I've ever seen" (Aoki, 2003). As a consequence of these opportunities, the number of laboratories involved in research with select agents is likely to grow, offsetting perhaps any exodus of researchers quitting the field to avoid the new regulations. It is not yet possible to discern the winners and losers among institutions, as the breakdown between grants and contracts to government, industry and university laboratories is not available.

\section{Governance Issues}

In addition to its direct impact on the conduct of biological research, the new regulatory regime in the United States also raises important issues for the governance of science and more generally for the relationship between science and the state. We can begin by noting some of the characteristics of the process so far:

Laws have been passed and regulations issued over a very short time period, with minimal input from the biology community.

The regulatory regime challenges many of the customary practices in biology laboratories.

There is little rapport and trust between the security and biology communities.

Federal funding for research on relevant topics has increased dramatically.
The general public(s) has not been represented in the process.

The last point is potentially the most important, but it has not received much attention in discussions of bioterrorism. A broad public interest in both national security and biological research is regularly invoked: 'the public must be protected from acts of bioterrorism' and 'the public benefits from research in biotechnology, particularly biomedical research.' Acknowledgement of these interests, however, has not translated into public participation in the policy process; instead 'the public' is imagined as an undifferentiated, passive body in need of management. This is very much a deficit model of public understanding, with the added twist that the public is not trusted to deal calmly with information, were it provided.

For example, in the aftermath of the 2001 anthrax letters, the government acknowledged that it did not have a coordinated response for getting consistent information to the public (or even to physicians); at the same time it was inhibited by the fear that communicating uncertainty would lead to panic (General Accounting Office, 2003; Freimuth, 2002: slide 4). In fact, although the media at the time were dominated by frenzied headlines and pictures of postal workers in full protective gear, in most places people remained relatively calm: public opinion data show that most Americans thought-reasonably enough - that they were more likely to get 'flu than anthrax or smallpox (Freimuth, 2002: slide 9).

Predictably, the only point on which the public has mobilised is around the 'not in my backyard' (NIMBY) issue of 
site selection for the new national biocontainment laboratories, where work on the most dangerous pathogens will be done. During the review period for choosing among the candidate locations, local protest movements sprang up in Davis, CA and Boston, MA to oppose their bids for funding (Council for Responsible Genetics, 2003; Pittman, 2003). As in other NIMBY situations the local protesters were more impressed by the possibility that pathogens might escape from the laboratories to contaminate their neighbourhoods than by the more remote benefits of new research on vaccines or medical treatments. ${ }^{4}$

Excluding the public from the policy response to bioterrorism might be justified on the grounds that its members lack relevant expertise or that broader participation would be a source of instability in the process (Collins and Evans, 2002). It is interesting, nonetheless, to speculate on the contribution that lay members of the public might make to policy formulation. The postal workers, for example, had local knowledge about the operation of the mail-sorting machines, which turned out to be the clue to how the anthrax toxin particles spread to remote locations; in the Collins and Evans (2002) schema they would count as members of the 'core-set' and thus relevant to policy making. Reframing the issues to ask why the risk of bioterrorism has been elevated to a position of high saliency and whether the costs to civil liberties of surveillance and restricted information flows are justified by that risk would involve a much broader public interest and call for much broader participation (Jasanoff, 2003; Wynne, 2003; Rip, 2003).

To date, however, the issues have re- mained defined in terms of the security discourse, and even the biology research community, which is the repository of the specialised knowledge needed for making judgments about select agents and laboratory practices, has enjoyed only limited participation. The process has been almost wholly top-down, with strikingly little input from the scientific community, especially if one looks for the voices of bench scientists rather than the elites who populate committees of the National Academy of Sciences or advisory boards to governmental agencies.

There are some obvious reasons why this should be so. Congress acted very swiftly following the 2001 terrorist attacks, and the legislated mandates have dominated the political response to the threat of bioterrorism. Moreover, the legislation mandated early deadlines for regulatory action, leaving little time for consultation with scientists. Equally important, the lack of established networks between the biological sciences and the security community meant that there was no obvious group of scientists to consult outside the small number who had had experience in the biodefence program: Ron Atlas, the 2002 President of the American Society for Microbiology, emerged as practically the only spokesman on bioterrorism for the academic research community. A final factor was the mismatch between the bureaucratic mindset of the security agencies and the more flexible organizational culture of the research laboratory, where regulations are more likely to be seen as part of the problem rather than a solution.

In terms of the typology proposed by Hagendijk and Kallerud (2003) this 
policy process is best described as corporatist and discretionary (in the sense that policy decisions have been left to government bodies). The institutions of national security, such as the relevant congressional committees, the Department of Defence, and the Department of Homeland Security, have framed the issues and controlled the discourse, with some input from organizations representing the scientific establishment, such as the NIH, the National Academy of Sciences, and American Society for Microbiology. To date there has been little opportunity for opponents of the policy to mobilise, although that may happen as the effects of the regulations are felt more widely.

\section{Biosafety Regulation: Is the RAC a Model?}

It is instructive to compare the current regulatory process to an earlier episode in the history of biotechnology, the introduction in the early 1970s of recombinant-DNA techniques that - it was feared - might pose a threat to the public welfare. The danger was that newly engineered organisms might infect laboratory workers or escape into the general environment where they would not only harm the public but could interfere with natural evolutionary processes: in short, that irretrievable damage might be done (Wade, 1977). At that time, the number of scientists involved in the new lines of research was relatively small, and in 1974 the qualms of a few leading scientists were enough to galvanise a moratorium on research, followed by a conference at Asilomar, CA in February 1975 which was attended by most of the leading researchers in the field. The Asilomar conference produced a consensus in favour of a scheme of graded safety precautions for various levels of hazard associated with particular experiments. A modified version of these safety regulations, overseen by Institutional Biosafety Committees (IBCs) at the local level and the Recombinant DNA Advisory Committee (RAC) at the national level, is still in effect today (National Institutes of Health, 2002).

Contemporary accounts (Wade, 1977) reveal that the Asilomar agreement and its translation into federal regulations were highly contentious. Nevertheless, 'the Asilomar moment' rather quickly attained iconic status as a virtually trouble-free process (see e.g. Talbot, 1983), and its creation is celebrated as an example of scientists engaging in responsible self-governance (National Research Council, 2003: 23). Helped by the fact that, in the absence of any demonstrated problems, the guidelines have been loosened rather than tightened, the RAC system is today accepted as a routine part of doing research in biotechnology. The system forms the basis for the recommendation of a recent committee of the National Academy of Sciences for a voluntary system for screening research proposals for bioterrorism concerns; the proposed system would utilise the institutions that have been established for recombinant DNA experiments by adding biosecurity to their responsibility for biosafety (National Research Council, 2003: 88-90).

The committee's proposal has obvious attractions for the biological scientists, as it would preserve professional autonomy in at least one part of the regulatory regime that is under construction. It also relieves the federal gov- 
ernment of the need to devise a new system to deal with the problems posed by dual-use information and then to sell that system to the scientific community. It does not, however, answer those critics who believe that a voluntary system leaves too many loopholes for comfort, especially because industrial laboratories are not included in the committee's proposed system (Ruppe, 2003).

The compliance problem facing the government and biologists can be framed in terms of a principal/agent analysis (Williamson, 1975; Guston, 2000). The state wishes the scientists to behave responsibly, whether in following government regulations, such as those requiring meticulous records of the status of all select agents, or in agreeing to subject their research and publications to screening procedures. Given the inconvenience and costs of following the new regulations, as well as the ongoing debate over whether bioterrorists would choose to use advanced biotechnology rather than agents that are available in nature, it is probable that some biologists will choose quietly to ignore the regulations. Comprehensive enforcement would require surveillance of thousands of research sites, something that clearly is not feasible. Thus, the success of the government's policy depends to a large degree on voluntary compliance, as much in those areas of regulation where there are legal sanctions for non-compliance as in the still voluntary areas of review of journal articles and (as proposed) research projects.

In the principal/agent framework, the optimal mix of incentives and penalties is decided by a type of cost-benefit analysis: will the new regime, with its mix of mandatory and voluntary elements - including the new funding - induce compliant behaviour without driving scientists out of the research areas that are subject to regulation? If the regulatory regime is seen as lacking legitimacy, the cooperation of the research community cannot be assumed. More specifically, if scientists believe the process has ignored their concerns and produced unworkable rules, they will be likely to evade the regulations or leave the field. Thus, the failure to include scientists in the formulation of the policy could have consequences for its successful implementation.

\section{Conclusion}

In the aftermath of the 2001 terrorist attacks, the U.S. scientific community has recognised the potential danger of bioterrorism and the need to respond (and seen to be responsive) to that danger. Legislative controls on access to select agents have been supplemented by voluntary screening procedures for journal articles and proposals for similar screening of research proposals.

This new regulatory regime in biotechnology demands nothing less than a cultural shift in the research practices in biotechnology laboratories. Cultural shifts, however, cannot be imposed from above; without the cooperation of the biologists and, indeed, the whole network of actors involved in producing new knowledge in the field, the regime will not succeed. The regulatory process to date has not been designed to elicit that cooperation: there has been little scope for participation by biologists in the process and the tight timetable for implementation of the regulations has led to confusion and not a little resent- 
ment among biologists in the field.

It is deceptively easy to suggest that the solution to these problems lies in engaging the scientific community in the policy process through membership in consultative bodies and education efforts. Although more participation by scientists could shape the regulatory regime in ways that would make it more acceptable to the research community, the task of creating such participation is far from trivial. The security and biology communities in effect speak different languages and face very different incentive structures. Persuading research scientists to devote time and energy to the implementation of the new regime could never be easy, and the early problems in the imposition of the new rules have squandered much good will. Indeed, many in the biology community hold the hope that the issue will go away with time, just as the disruption to the laboratory from the introduction of the RAC system dissipated with the progressive loosening of its rules.

Regulation to reduce the risk of bioterrorism is likely to follow a different path, however. New discoveries and the emergence of new diseases, such as SARS, will add to the list of select agents and technologies of concern, and the logic of action and reaction that has fuelled arms races in other types of weapons will ensure that the state's interest in regulating biotechnology remains high. We can conclude that the research environment for biology has undergone a permanent shift, the full consequences of which are still to be revealed.

\section{Acknowledgements}

The author thanks the Science Studies Unit of the University of Edinburgh for its hospitality during Fall 2003.

\section{Notes}

1 It is obvious that, given the international character of biotechnology, only an international control regime can be effective in limiting the risks of bioterrorism. Discussion of the conditions needed to construct such a regime is, however, beyond the scope of this article.

2 The current lists can be found at: http:// www.cdc.gov/od/sap/general.htm and http://www.cdc.gov/od/sap/addres.htm.

3 Available at "http://www.fas.org/irp/ offdocs/nsdd/nsdd-189.htm" http:// www.fas.org/irp/offdocs/nsdd/nsdd189.htm. Most American universities do not allow classified research on campus, so any move to classify a research project is tantamount to taking it out of the academy.

4 In September 2003 NIAID announced that Boston University and the University of Texas Medical Branch had been chosen for the two new national laboratories (NIAID, 2003).

\section{References}

Ad Hoc Faculty Committee on Access to and Disclosure of Scientific Information 2002 "In the Public Interest." Massachusetts Institute of Technology (12 June). http:/ / web.mit.edu / faculty/ reports / publicinterest.pdf.

American Association for the Advancement of Science [AAAS]

2003a AAAS Report XXVIII: Research \& Development FY 2004. Washington, DC: American Association for the Advancement of Science. http://www.aaas.org/ $\mathrm{spp} / \mathrm{rd} / \mathrm{rd} 04$ main.htm. 
2003b "New DHS Receives Final R\&D Portfolio of \$1.05 Billion, Funding for Project BioShield." AAAS R\&D Funding Update September 24, 2003. http:// www.aaas.org/spp/rd/fy04.htm.

American Society for Microbiology

2002a "ASM Comments to the CDC on the July 2 Federal Register Notice on Proposed Data Collection for Notification of Possession of a Select Agent." (11 July). http://www.asm.org/Policy/ index.asp?bid=565.

2002b "ASM Comments on CDC Revision to List of Select Agents and Toxins." (13 September). http://www.asm.org/ Aoki, N. Policy/index.asp?bid=565.

2003 "A Shot in the Arm for Biotech." Boston Globe. (5 February): 5.

Collins, H. \& Evans, R.

2002 "The Third Wave of Science Studies: Studies of Expertise and Experience." Social Studies of Science 32(2): 235-296. Cooter, R., Harrison, M. \& Sturdy, S.

1998 War, Medicine and Modernity. Phoenix Mill, Glouscestershire: Sutton.

Council for Responsible Genetics

2003 "CRG Dismayed by Federal Decision to Fund B.U.'s \$1.6 Billion Bioterrorism Lab Proposal." CRG Press Release (30 Doel, R. September).

2003 "Constituting the Postwar Earth Sciences: The Military's Influence on the Environmental Sciences after 1945." Social Studies of Science 33 (October).

Elias, $\mathrm{P}$.

2003 Scientists say post-9/11 rules hurting research. Associated Press. (11 September). http:/ / www.msnbc.com/news/ 965259.asp!.

Fauci, A.

2003 “Testimony on the Fiscal Year 2004 Budget Request before the Senate Subcommittee on Labor-HHS-Education Appropriations." (April 8). http:// www.niaid.nih.gov/director/congress/ 2003/fy2003budget.html.

Freimuth, V.

2002 "The Anthrax Experience: 'Lessons Learned." Slide Presentation (26 August). http://www.hhs.gov/ophp/presentations/freimuth.html.
General Accounting Office

2003 Bioterrorism: Public Health Response to Anthrax Incidents of 2001. GAO-04152 (October).

Guston, D.

2000 Between Politics and Science. Cambridge, UK: Cambridge University Press.

Hagendijk, R, \& Kallerud, E.

2003 "Changing Conceptions and Practices of Governance in Science and Technology in Europe: A Framework for Analysis." STAGE (Science, Technology and Governance in Europe) Discussion Paper 2 (March).

Hilgartner, S.

1997 "Access to Data and Intellectual Property: Scientific Exchange in Genome Research." Pp. 28-39 in National Research Council, Intellectual Property Rights and the Dissemination of Research Tools in Molecular Biology. Washington, DC: The National Academies Press.

Jasanoff, S.

2003 "Breaking the Waves in Science Studies: Comment on H. M. Collins and Robert Evans, 'The Third Wave of Science Studies."” Social Studies of Science 33(3): 389-400.

Journal Editors and Authors Group

2003 "Statement on Scientific Publication and Security." Science Online 299 (5610): 1149. http://www.sciencemag. Kaiser, J. org/cgi/reprint/299/5610/1149.pdf.

2003 "Bioterrorism Drives Record NIH Request.” Science 295 (1 February): 785.

King, N.B.

2003 "The Influence of Anxiety: September 11, Bioterrorism, and American Public Health," Journal of the History of Medicine and Allied Sciences 58 (October): 433-41.

Leitenberg, $\mathrm{M}$.

2003 "BiologicalWeapons and 'Bioterrorism' in the First Years of the $21^{\text {st }}$ Century." Paper prepared for Conference on "The Possible Use of Biological Weapons by Terrorists Groups: Scientific, Legal, and International Implications." Rome (16 April 2003; updated 3 April 2003). http:/ /www.fas.org/bwc/papers/bw20th.htm 
National Academy of Sciences

1982 Scientific Communication and $\mathrm{Na}-$ tional Security. Washington, DC: National Academies Press.

National Institute of Allergy and Infectious Diseases (NIAID)

2003 "NIAID Funds Construction of Biosafety Laboratories." NIAID News (30 September 2003).

National Institutes of Health

2002 NIH Guidelines for Research Involving Recombinant DNA Molecules. (April). http://www4.od.nih.gov/oba/rac/ guidelines/guidelines.html.

National Research Council of the National Academies

2003 Biotechnology Research in an Age of Terrorism: Confronting the Dual Use Dilemma. Washington, DC: National Academies Press.

Patrinos, A. \& Drell, D.

2002 “The Times They Are A-Changing." Nature 417 (6 June): 589-90.

Pearton, M.

1982 The Knowledgeable State: Diplomacy, War and Technology. London: Burnett. Perkel, J.

2003 "US Amends 'Select Agent' Regs." The Scientist (10 November). http://www. biomedcentral.com/news/20031110/ 06/.

Pittman, R.

2003 "Biosafety Lab Would Imperil City of Davis, Some Contend.” Los Angeles Times (22 September).

Rip, A.

2003 "Constructing Expertise: In a Third Wave of Science Studies?" Social Studies of Science 33 (3): 419-434.

Ruppe, D.

2003 "Report on Screening U.S. Biological Research Draws Mixed Reviews." Global Security Newswire (8 October).

Salerno, R., Barnett, N., \& Koelm, J.

2003 "Balancing Security and Research at Biomedical and Bioscience Laboratories." SAND No. 2003-0701C. Paper presented at the conference "BTR 2003: Unified Science and Technology for Reducing Biological Threats and Countering Terrorism," University of New Mexico, Albuquerque, 19-21 March.
Shane, S.

2003 "Charges Against Scientist Widened." Baltimore Sun (4 September), 3A.

Smithson, A. \& Levy, L.

2002 "Ataxia: The Chemical and Biological Terrorism Threat and the US Response." Stimson Center Report No. 35. http:// www.stimson.org/cbw/pubs. $\operatorname{cfm}$ ? ID $=12$. !

Stafford, N.

2003 "Life Sciences Expected to be Central to the EU's New Program of Security Research." The Scientist (22 October). http://www.biomedcentral.com/ news/20031022/03.

Stockholm International Peace Research Institute (SIPRI)

1973 "The Problem of Chemical and Biological Warfare." Chapter 3 in CB Weapons Today, J. P. P. Robinson, C-G. Heden, \& H. von Scrieb, eds. New York: Humanities Press.

Talbot, B.

1983 "Development of the National Institutes of Health Guidelines for Recombinant DNA Research." Public Health Reports 98 (August): 361-68. Reprinted in A. P. Iannone, ed., Contemporary Moral Controversies in Technology. Oxford: Oxford University Press, 1987.

Tilly, C.

1992 Coercion, Capital and European States, AD 999-1990. Oxford: Blackwell.

Wade, $\mathrm{N}$.

1977 The Ultimate Experiment: Man-made Evolution. New York: Walker and Co.

Williamson, O.

1975 Markets and Hierarchies. New York: Free Press.

Wynne, B.

2002 "Seasick on the Third Wave? Subverting the Hegemony of Propositionalism: Response to Collins \& Evans." Social Studies of Science 33(3): 401-417.

\section{Judith Reppy}

Department of Science \& Technology Studies

Cornell University

jvr2@admin.is.cornell.edu 